\title{
Slag Metallurgy and Metallurgical Waste Recycling
}

\author{
ZHIWEI PENG,${ }^{1,5}$ DEAN GREGUREK, ${ }^{2,6}$ CHRISTINE WENZL, ${ }^{3,7}$ \\ and JESSE F. WHITE ${ }^{4,8}$ \\ 1.-School of Minerals Processing and Bioengineering, Central South University, Changsha \\ 410083, Hunan, China. 2.-RHI AG, Technology Center Leoben, Magnesitstrasse 2, 8700 Leoben, \\ Austria. 3.-RHI AG, Wienerbergstrasse 9, 1100 Vienna, Austria. 4.-Elkem Carbon AS, 4675 \\ Kristiansand, Norway. 5.-e-mail: zwpeng@csu.edu.cn. 6.-e-mail: Dean.Gregurek@rhi-ag.com. \\ 7.—e-mail: Christine.Wenzl@rhi-ag.com. 8.—e-mail: jesse.white@elkem.no
}

Slag is a typical byproduct generated during hightemperature metallurgical processes. It must be treated appropriately to meet the increasingly strict environmental requirements and to realize the economic benefits. 1,2 The present topic, "Slag Metallurgy and Metallurgical Waste Recycling," collects eight articles, which demonstrate the progress of slag metallurgy and metallurgical waste recycling toward environmental and economic sustainability.

Copper slag originating from the copper smelting industry is worthy of particular attention due to its massive generation and enrichment of multiple valuable metals. One of the most important goals of copper slag metallurgy is to minimize copper losses to slag from entrained $\mathrm{Cu}$ droplets during the smelting of copper concentrate, ${ }^{3}$ often achieved by decreasing the slag viscosity via the addition of fluxing agents. In the first article, entitled "Investigation of Copper Losses to Synthetic Slag at Different Oxygen Partial Pressures in the Presence of Colemanite," Aydin Rusen et al. explored the feasibility of using colemanite as an additive to control the copper loss in a synthetic matte-slag mixture at $1250^{\circ} \mathrm{C}$ under different partial pressures of oxygen $\left(10^{-7} \mathrm{~atm}, 10^{-9} \mathrm{~atm}\right.$, and $\left.10^{-11} \mathrm{~atm}\right)$. It was found that the copper amount in the slag decreased with the increasing addition of calcined colemanite under all oxidizing atmospheres. The results were also supported by the calculated and simulated related liquidus temperatures and phases diagrams of the fayalite-type slag.

In another article, entitled "Effects of Some Additives on Copper Losses to Matte Smelting Slag," the same group of authors evaluated the effects of $\mathrm{CaO}$ and $\mathrm{B}_{2} \mathrm{O}_{3}$ additions on copper losses

Zhiwei Peng, Dean Gregurek, and Jesse White are the JOM advisors for the Pyrometallurgy Committee of the TMS Extraction \& Processing Division, and guest editors for the topic Slag Metallurgy and Metallurgical Waste Recycling in this issue. to slag and compared the results with those of calcined colemanite addition. The results of matteslag-flux at $1250^{\circ} \mathrm{C}$ under nitrogen atmosphere showed that the addition of each up to $4 \%$ led to a gradual decrease in the copper content of initial slag. Beyond this value, the losses increased markedly with increasing $\mathrm{CaO}$ and $\mathrm{B}_{2} \mathrm{O}_{3}$ additions, while further addition of calcined colemanite exerted a negligible effect on the losses, showing a plateau at about $0.3 \mathrm{wt} . \% \mathrm{Cu}$. The experimental results agreed well with the calculated phase diagrams in which the liquid slag region was enlarged caused by the addition of the calcined colemanite. Obviously, calcined colemanite may find broader applications in future slag metallurgy.

After copper slag is generated, it is essential to characterize its properties in detail for subsequent treatment. In the third article, entitled "Mineralogical Characterization of Copper Slag from Tongling Nonferrous Metals Group China," Tiejun Chun et al. investigated the mineralogical characteristics of a typical copper slag (40.21 wt.\% Fe, 0.79 wt.\% $\mathrm{Cu}, 0.24$ wt. $\% \mathrm{~Pb}$, and 2.80 wt. $\% \mathrm{Zn}$ ) in China using a variety of techniques. It was shown that the dominant phases of the slag were fayalite, a glassy substance and magnetite, accompanying minor amounts of copper matte, metallic copper and other complex lead and zinc minerals. The slag mineralogy implied that physical beneficiation was not suitable for recovering the metals due to its complicated occurrences. Instead, pyrometallurgical processes appeared promising in the metal recovery. This study highlights the importance of mineralogical characterization in the selection and optimization of process parameters for slag treatment.

For copper slag recycling, the fourth article, entitled "Mechanism of Mineral Phase Reconstruction for Improving the Beneficiation of Copper and Iron from Copper Slag," by Zhengqi Guo et al., reported on the use of a compound additive in 
modifying copper slag to recover iron and copper contained within it. They found that the combined use of burnt lime and a compound additive improved the fluidity of the molten slag, thereby facilitating the coalescence and growth of fine particles of the target minerals. The mineral phase construction in copper slag was promoted, converting more iron and copper into magnetite and matte/ metallic copper, respectively. After simple beneficiation, such as froth flotation and magnetic separation, the percentage of iron in the form of magnetite increased from $32.86 \%$ to $65.12 \%$, and that of copper in the form of magnetic copper and copper sulfide rose from $80.00 \%$ to $90.33 \%$. The study demonstrates a good example of highly efficient recovery of metals from copper slag based on phase reconstruction.

Titanium-rich slag is another waste product that has emerged as an indispensable raw material for many titanium uses due to the lack of natural Tibearing resources. In the fifth article, entitled "Synthesis and Characterization of Titanium Slag from Ilmenite by Thermal Plasma Processing," Sneha Samal disclosed the advantages of thermal plasma processing of ilmenite for production of titania-rich slag. By the rapid plasma process, pig iron containing $98.8 \% \mathrm{Fe}$ and slag containing $84.5 \%$ $\mathrm{TiO}_{2}$ were successfully separated from ilmenite subjected to pre-reduction at $1200^{\circ} \mathrm{C}$.

Electric arc furnace (EAF) slag is a pyrometallurgical byproduct originating from EAF steelmaking. To improve its recyclability for wider applications, iron oxide inside the slag must be reduced. In the sixth article, entitled "Reduction Kinetics of Electric Arc Furnace Oxidizing Slag by Al-Fe Alloy," Jaehong Lee et al. explored the kinetics of aluminum reduction of molten slag using $\mathrm{Al}-\mathrm{Fe}$ alloy. It was demonstrated that the reduction required a temperature of at least $1500^{\circ} \mathrm{C}$ and the slag basicity at 1.1 or higher. The reduction rate of iron oxide increased with the initial slag temperature and slag basicity. This study offers a new research direction for enhancing the economic value of the reduced EAF oxidizing slag by using a high-quality aluminum dross or low-quality aluminum scrap.

In slag metallurgy, molten slag properties, such as electrical conductivity, are important for determining the process parameters for alloy production. Such importance has been partially revealed by the results reported in the seventh article entitled, "Estimation Model for Electrical Conductivity of $\mathrm{CaF}_{2}-\mathrm{CaO}-\mathrm{Al}_{2} \mathrm{O}_{3}$ Slags" by Guan-Yong Shi et al. It introduced a model for estimating electrical conductivities of multi-component slags in which the relationship between electrical conductivity and the temperature of the slag was described by the Arrhenius law. The predicted values of electrical conductivity in $\mathrm{CaF}_{2}-\mathrm{Al}_{2} \mathrm{O}_{3}, \mathrm{CaF}_{2}-\mathrm{CaO}, \mathrm{CaO}-\mathrm{Al}_{2} \mathrm{O}_{3}$, and $\mathrm{CaF}_{2}-\mathrm{CaO}-\mathrm{Al}_{2} \mathrm{O}_{3}$ systems were in good agreement with the experimental values. This method shows the potential in estimating the conductivity of complex systems using simple binary and ternary data. It represents a marked progress toward improved high-temperature conductivity characterization.

Nowadays, metallurgical slag may also be used to refine advanced materials, such as solar-grade silicon, a key material for converting solar energy into electric energy within a solar cell. ${ }^{4}$ In the last article, entitled "Reaction Mechanism and Kinetics of Boron Removal from Metallurgical-Grade Silicon Based on $\mathrm{Li}_{2} \mathrm{O}-\mathrm{SiO}_{2}$ Slags," Huixian Lai et al. demonstrated the feasibility of removing boron, a detrimental element, from metallurgical-grade silicon by $\mathrm{Li}_{2} \mathrm{O}-\mathrm{SiO}_{2}$ slag refined under air atmosphere. The boron concentration in metallurgical-grade silicon was successfully reduced from $8.6 \mathrm{ppmw}$ to $0.4 \mathrm{ppmw}$ after slag refining for $0.5 \mathrm{~h}$ at $1700^{\circ} \mathrm{C}$. The primary boron removal was a result of a large amount of oxidation and volatilization of boron to the atmosphere in the form of gaseous borates. With further optimization of the composition, more stimulating usages of the slag in relevant fields can be envisioned.

The following papers being published under the topic of Slag Metallurgy and Metallurgical Waste Recycling embody the development of modern technologies for slag metallurgy and metallurgical waste recycling. The innovations reported are expected to be motivating for both process and physical metallurgy specialists. To download any of the papers, follow the url http://link.springer.com/ journal/11837/68/9/page/ 1 to the table of contents page for the September 2016 issue (vol. 68, no. 9).

- "Investigation of Copper Losses to Synthetic Slag at Different Oxygen Partial Pressures in the Presence of Colemanite" by Aydin Rusen, Bora Derin, Ahmet Geveci, and Yavuz Ali Topkaya.

- "Effects of Some Additives on Copper Losses to Matte Smelting Slag" by Aydin Rusen, Ahmet Geveci, Yavuz Ali Topkaya, and Bora Derin.

- "Mineralogical Characterization of Copper Slag from Tongling Nonferrous Mteals Group China" by Tiejun Chun, Chao Ning, Hongming Long, Jiaxin $\mathrm{Li}$, and Jialong Yang.

- "Mechanism of Mineral Phase Reconstruction for Improving the Beneficiation of Copper and Iron from Copper Slag" by Zhengqi Guo, Deqing Zhu, Jan Pan, and Feng Zhang.

- "Synthesis and Characterization of Titanium Slag from Ilmenite by Thermal Plasma Processing" by Sneha Samal.

- "Reduction Kinetics of Electric Arc Furnace Oxidizing Slag by Al-Fe Alloy" by Jaehong Lee, Joon Seok Oh, and Joonho Lee. 
- "Estimation Model for Electrical Conductivity of $\mathrm{CaF}_{2}-\mathrm{CaO}-\mathrm{Al}_{2} \mathrm{O}_{3}$ Slags" by Guan-Yong Shi, TingAn Zhang, Zhi-He Dou, and Li-Ping Niu.

- "Reaction Mechanism and Kinetics of Boron Removal from Metallurgical-Grade Silicon Based on $\mathrm{Li}_{2} \mathrm{O}-\mathrm{SiO}_{2}$ Slags" by Huixian Lai, Liuqing Huang, Chenghao Lu, Ming Fang, Wenhui Ma, Pengfei Xing, Jintang Li, and Xuetao Luo.

\section{REFERENCES}

1. P. Drissen, A. Ehrenberg, M. Kühn, and D. Mudersbach, Steel Res. Int. 80, 737 (2009).

2. Z. Peng and J.Y. Hwang, Int. Mater. Rev. 60, 30 (2015).

3. P. Coursol, N.C. Valencia, P. Mackey, S. Bell, and B. Davis, JOM 64, 1305 (2012).

4. M. Forster, P. Wagner, J. Degoulange, R. Einhaus, G. Galbiati, F.E. Rougieux, A. Cuevas, and E. Fourmond, Sol. Energy Mater. Sol. Cells 120, 390 (2014). 